\title{
EVALUATION METHODS OF INVESTMENT ATTRACTIVENESS OF UKRAINIAN AGRICULTURAL ENTERPRISES
}

\author{
Nadiya Davydenko', Halyna Skryphyk ${ }^{2}$ \\ National University of Life and Environmental Sciences of Ukraine, Ukraine
}

\begin{abstract}
The purpose of the article is to reveal scientific approaches to determining investment attractiveness of enterprises. Evaluation methods of investment attractiveness of enterprises, which are based on various expert assessments, on statistical information, and also combined methodologies based on expert and statistical calculations are investigated. Decision-making criteria on the appropriateness of investment are determined. Methodology. To determine investment attractiveness of agrarian enterprise on the basis of rating and analytical assessment, it is necessary to use an integrated approach and take into account certain set of indicators. During developing and organizing rating restrictions, we conducted an analysis of groups of indicators, which combined characterize investment attractiveness in a complex way, taking into account specifics of the industry. Results. Application of this approach allows quickly evaluating perspectives of funds investing and the reliability of the investment object. At the same time, the investment potential of company and investment risk are expressed by one general indicator, which allows applying rating comparisons. In order to approbate research results, seven agrarian enterprises with positive profitability and appropriate level of financial autonomy are selected. Based on financial statements, we determined their investment attractiveness and rating. Practical implications. Proposed calculation methodology covers all major processes occurring in different functional sectors of the internal environment of agrarian enterprise, which ensures a systematic view of the subject of management, which enables to identify all the strengths and weaknesses, as well as to create a strategy for prospective development on this basis. Presented methodology for the evaluation of investment attractiveness of enterprises can be successfully applied in agrarian enterprises as during the choice of priority directions of investment investments, as well as for operating current costs, technologies, etc. Applying in practice the abovementioned recommendations will increase the objectivity of evaluation of investment attractiveness, will increase the flow of necessary funds to the company.
\end{abstract}

Key words: investment attractiveness, methods of analysis, rating and analytical valuation, agrarian enterprises.

JEL Classification: Q14, M21, R30

\section{Introduction}

In conditions of investment resources deficit and further high risk of investment activity in the agricultural production of Ukraine, information on the level of investment attractiveness of potential consumer of investments is important for potential investors. The necessity to study investment attractiveness, create conditions for its growth, and develop a mechanism for attracting investment into enterprises of agricultural sector determines the relevance of our research.

A detailed analysis of literary sources suggests that the overwhelming majority of key theoretical considerations for the evaluation of investment attractiveness have been developed quite thoroughly. However, traditionally, investment attractiveness of enterprise is considered as a function of its financial condition. Insufficient attention is paid to factors such as investment and innovation potential, economic growth, and competitive positions in the market. Calculations are mainly limited to retrospective analysis, which highlights the situation that occurred in the previous period.

Investment attractiveness plays an important role in activating investment processes. Its role lies in the fact that potential investors need to be convinced in the expediency of investments with help of concrete indicators.

Today, the issue of developing a methodology and improving methods of evaluating investment attractiveness of agrarian enterprise becomes relevant. Investment attractiveness of agrarian enterprise is multilevel integrated characteristic.

\footnotetext{
Corresponding author:

${ }^{1}$ Department of Finance, National University of Life and Environmental Sciences of Ukraine.

E-mail: davidenk@ukr.net

${ }^{2}$ Department of Finance, National University of Life and Environmental Sciences of Ukraine.

E-mail:ga_skrypnyk@ukr.net
} 
At the present stage in economic literature, notion of essence and analysis of the main approaches to the valuation of investment attractiveness were considered in a number of works by well-known domestic and foreign researchers, in particular, I. O. Blank, F.V. Bandurin, S. A. Butkevych, I. M. Vahovych, F. P. Gayduksky, T. V. Majorova, S. S. Chernysh, T. A. Cherniavska, O. M. Yastremska.

However, it should be noted that, despite numerous publications, there is still no single point of view on methodological approaches to analysis and evaluation of investment attractiveness, which indicates the need for further research in this direction.

\section{Problem statement}

Nowadays one of theimportantissuesisanimprovement of methodological approaches to determining investment attractiveness of agrarian enterprises taking into account sectoral features and developing an active mechanism for attractiveness evaluation of investment object. The relevance of this issue is conditioned, first of all, to the fact that in modern conditions of management, the majority of agrarian enterprises need to attract additional investment resources for pursuing activities. And investor, in turn, should identify the potential object for investing resources and focus on investment attractiveness of enterprise.

The purpose of the paper is to open up and develop methodological approaches to improve evaluation of investment attractiveness of agrarian enterprises on the basis of rating approach, taking into account sectoral peculiarities.

\section{Methods of analysis of investment attractiveness of enterprise}

Estimation of investment attractiveness of enterprise is carried out directly in a number of methods developed by ministries (departments), National Bank of Ukraine and commercial banks. The basis of such methodological approaches has been laid since 1998 by Agency for Prevention of Bankruptcy of Enterprises and State Tax Administration of Ukraine.

At the legislative level, on the initiative of Agency for Prevention of Bankruptcy of Enterprises and Organizations, Methodology for Integral Assessment of the Investment Attractiveness of Enterprises and Organizations has been developed. This Methodology is developed in accordance with the Law of Ukraine "On Investment Activity", Decree of President of Ukraine "On Establishment of Agency for Prevention of Bankruptcy of Enterprises and Organizations" and Regulation on Register of Insolvent Enterprises and Organizations with view to defining integral indicator of investment attractiveness of enterprises and organizations, accelerating implementation of investment projects, promotion of domestic and foreign entrepreneurs' investments, provision of methodical assistance to specialists involved in creation measures for sanitation of production sector.

According to Methodology, investment attractiveness of enterprise is level of satisfaction of financial, industrial, organizational and other requirements or interests of an investor with respect to a particular enterprise, which can be determined or evaluated by values of relevant indicators, including integral assessment (Methodology, 1998).

At the stage of enterprise creation, investment attractiveness affects model of future work of enterprise, on basis of which it is possible to predict advantages and opportunities of strategic investment management in the long run, as well as to insure against risks both at decision-making level about profitability or unprofitability of investment, and risk inadequate reaction of subjects of investment planning and their expectations (Ponomarenko and others, 2003).

O.M. Yastremskaya claims that investment attractiveness is determined by using methods of multi-factor analysis to identify explicit and implicit tendencies in their use in the first stage, and regression analysis based on the genetic algorithm in the second stage (Yastremskaya, 2004).

Investment attractiveness of enterprise is set of characteristics of its financial, economic and managerial activity, prospects of development and possibility of investment resources attracting. Evaluation of investment attractiveness of enterprise is integral characteristic of its internal environment (Borsch, Gerasimova, 2007).

The essence of the methodology of integrated assessment of investment attractiveness is carried out in analysis conducting at following stages:

1) assessment of the financial condition of investment object;

2) determining the importance of group and individual indicators based on expert assessments;

3) determination of the fraction of the scale of variation set;

4) definition of ranked value for each indicator;

5) investment attractiveness integral indicator calculation (Methodology, 1998).

It should be noted that this methodology has its disadvantages; in particular, it does not take into account inter-industry specifics enterprises activity. Also, a financial analysis of investment attractiveness of an enterprise according to this methodology is rather cumbersome since it involves the calculation of more than forty indicators in terms of business activities of the enterprise. Obtained results require the processing and synthesis to determine more significant indicators, which involves experts (which entails additional costs).

However, I. Bakhovych notes that definition of integral indicator and assessment of investment 
attractiveness of enterprise should be carried out at the level of a separate region in order to identify the most investment-attractive enterprises of the region. This, in turn, will allow the attraction of foreign investors and stimulate domestic investment in the designation of enterprise (Vakhovych, 2014).

Theory of financial analysis uses a large number of techniques to determine investment attractiveness of enterprises. All developed in domestic and world practice methods of evaluation of investment attractiveness in relation to the source of information can be divided into three broad groups:

1) methods based on various expert assessments;

2) methods based on the statistical information;

3) combined methods based on expert and statistical calculations (Pylypenko, 2010).

In the economic literature, I. O. Blank considers investment attractiveness from the point of view of financial position of company as "integral characteristic of individual firms - objects of possible investment from the perspective of development, volumes and prospects of product sales, efficiency of asset utilization, their liquidity, solvency and financial sustainability" (Blank, 2001).

In turn, A. Gaiducky proposes to use the method of comparisons, which should cover the following main components of investment process: comparison between investment objects, between subjects of investment (investors), and between investment conditions (factors of investment attractiveness) (Gaiduckiy, 2004).

Objective, expedient, and competitive system of appraisal indicators of investment attractiveness, as noted by S. S. Chernysh, should take into account the following conditions:

1) a limited number of indicative indicators directly affecting investment decision-making;

2) use in calculation of indicators of public accounting and statistical reporting data, minimizing the use of internal information;

3) the possibility of carrying out a rating assessment of company's activities in relation to other economic entities, as well as in time (Chernysh, 2013).

Consequently, existing methods of determining the level of investment attractiveness not always meet investor's objective and sufficient for decision-making information. Therefore, there arises issue towards the creation of a unified system of evaluation indicators, which would allow conducting an objective and comprehensive analysis of enterprises' investment attractiveness in the framework of the chosen mathematical toolkit.

In our opinion, in order to fully assess investment attractiveness of enterprise, quantitative and qualitative assessment of characteristics of enterprise should be taken into account: capital structure, liquidity and solvency of the enterprise, transparency of senior management's activities, and level of liability to investors, the nature of conflicts of corporate interests, and enterprise's business reputation.

\section{Research methodology}

For Ukraine in the difficult period of crisis state of the economic system, solution to the question of increasing the investment potential means creating mutually beneficial conditions for the placement of financial resources of investment entities that form a comprehensive basis for recreating the economic and social spheres of region's life.

One of the methods for assessing investment attractiveness is a rating of the issuer. This methodology is based on analysis of financial reporting data. This method involves assessing company's financial condition by calculating such indicators: liquidity, solvency, financial stability, business activity, insolvency and probability of bankruptcy (Gotra, 2017). After calculation, these indicators of the enterprise are compared with each other and investor chooses the most optimal one from his point of view for investing.

In turn, Y. V. Skrypnyk, in order to determine investment attractiveness of agrarian enterprise on the basis of scoring, uses an integrated approach, takes into account certain set of indicators. In developing and organizing rating constraints, the author analysed four groups of indicators, which combined characterize investment attractiveness in a complex way, taking into account the specifics of the industry (Skrypnyk, 2016). According to this points' method, we will analyse 7 agrarian enterprises (Table 1) where is investment attractiveness of a number of points evaluated as follows: 4 - attractive zone, 3 - satisfactory, 2 - acceptable, 1 risky, 0 - absolutely risky.

Analysing the indicators of Table 1, we note that of seven companies, four are located in an attractive zone. Two enterprises - PAE "Avangard" and ALLC "Luchansk-2" are in the satisfactory zone and only one enterprise - LLC "Urozhaina Ukraina" - in acceptable zone.

Thus, a proposed list of indicators makes it possible to take into account such important components of investment attractiveness of agrarian enterprise as resource productivity and business activity, quality of labour force, financial stability, opportunities for the economic growth and efficiency of economic activity. In addition, the lack of value measures makes this technique independent from the impact of inflation, which allows using it for the analysis of time trends.

The next step is rating assessment of the financial condition of agrarian enterprises for investment attractiveness (Table 2).

According to the calculations, APC "Labunsky" is identified as the most investment-attractive enterprise and the least attractive for investments - LLC "Luchanske-2". The most significant indicators are considered such as profitability and efficiency of assets 
Table 1

Investment attractiveness points evaluation of agrarian enterprises of Ukraine, 2016

\begin{tabular}{|c|c|c|c|c|c|c|c|c|}
\hline \multirow[b]{2}{*}{ Indicator } & \multirow[b]{2}{*}{$\begin{array}{c}\text { Attractive } \\
\text { zone }\end{array}$} & \multicolumn{7}{|c|}{ Enterprise } \\
\hline & & $\begin{array}{c}\text { APC } \\
\text { "Labunsky" }\end{array}$ & $\begin{array}{l}\text { LLC "Agro- } \\
\text { Leader- } \\
\text { Ukraine" }\end{array}$ & $\begin{array}{c}\text { LLC } \\
\text { "Maslivske" }\end{array}$ & $\begin{array}{c}\text { LLC } \\
\text { "Urozhaina } \\
\text { Ukraina" }\end{array}$ & $\begin{array}{l}\text { LLC “TAK- } \\
\text { AGRO” }\end{array}$ & $\begin{array}{c}\text { PAE } \\
\text { "Avangard" }\end{array}$ & $\begin{array}{c}\text { ALLC } \\
\text { "Lychanske } \\
-2 "\end{array}$ \\
\hline $\begin{array}{l}\text { Coefficient of fixed } \\
\text { assets depreciation }\end{array}$ & $<20 \%$ & 0,55 & 0,39 & 0,34 & 0,20 & 0,26 & 0,32 & 0,63 \\
\hline $\begin{array}{l}\text { Return on capital of } \\
\text { main funds }\end{array}$ & $>0,8$ & 24,1 & 1,69 & 13,2 & 27,5 & 1,14 & 2,52 & 1,09 \\
\hline Return on equity & $>0,4$ & 0,7 & 0,94 & 1,91 & 0,90 & 1,36 & 1,53 & 2,07 \\
\hline $\begin{array}{l}\text { Turnover of current } \\
\text { assets }\end{array}$ & $>2$ & 0,6 & 0,81 & 1,53 & 0,56 & 0,80 & 1,21 & 0,79 \\
\hline Absolute liquidity ratio & $>0,2$ & 0,15 & 0,65 & 2,2 & 0,005 & 0,001 & 0,12 & 0,21 \\
\hline $\begin{array}{l}\text { Current liquidity ratio } \\
\text { (coverage) }\end{array}$ & $>2$ & 17,42 & 17,43 & 6,9 & 1,96 & 2,18 & 2,90 & 1,46 \\
\hline $\begin{array}{l}\text { Coefficient of financial } \\
\text { independence } \\
\text { (autonomy) }\end{array}$ & $>0,6$ & 0,97 & 0,92 & 0,86 & 0,55 & 0,63 & 0,84 & 0,34 \\
\hline Return on basic activity & $>25 \%$ & 14,2 & 24,06 & 37,7 & 0,4 & 28,79 & 20,76 & 21,8 \\
\hline Return on assets & $>15 \%$ & 22,6 & 26,24 & 55,8 & 0,7 & 48,90 & 26,41 & 38,65 \\
\hline Return on sales & $>20 \%$ & 23,9 & 32,08 & 29,2 & 0,4 & 35,98 & 17,22 & 18,60 \\
\hline Points & & 4 & 4 & 4 & 2 & 4 & 3 & 3 \\
\hline
\end{tabular}

Calculated by the authors on the basis of financial statements of enterprises

Table 2

Rating estimation of investment attractiveness of agrarian enterprises of Ukraine, 2016

\begin{tabular}{|c|c|c|c|c|c|c|c|}
\hline \multirow[b]{2}{*}{ Indicator } & \multicolumn{7}{|c|}{ Enterprise } \\
\hline & $\begin{array}{c}\text { APC } \\
\text { "Labunsky" }\end{array}$ & $\begin{array}{l}\text { LLC “Agro- } \\
\text { Leader- } \\
\text { Ukraine" }\end{array}$ & $\begin{array}{c}\text { LLC } \\
\text { "Maslivske" }\end{array}$ & $\begin{array}{c}\text { LLC } \\
\text { "Urozhaina } \\
\text { Ukraina" }\end{array}$ & $\begin{array}{c}\text { LLC } \\
\text { “TAK-AGRO” }\end{array}$ & $\begin{array}{c}\text { PAE } \\
\text { "Avangard" }\end{array}$ & $\begin{array}{c}\text { ALLC } \\
\text { "Lychanske-2" }\end{array}$ \\
\hline Financial dependence & 1,03 & 1,09 & 1,16 & 0,45 & 1,59 & 1,19 & 2,9 \\
\hline Current liquidity & 17,42 & 17,43 & 6,9 & 1,96 & 2,18 & 2,9 & 1,46 \\
\hline Liquid ratio & 3,67 & 18,39 & 6,4 & 1,08 & 1,54 & 1,27 & 0,6 \\
\hline Absolute liquid ratio & 0,149 & 0,65 & 2,2 & 0,005 & 0,001 & 0,12 & 0,21 \\
\hline Return on assets & 14,2 & 0,24 & 0,37 & 0,4 & 0,29 & 0,21 & 0,2 \\
\hline Return on equity & 12,0 & 0,26 & 0,55 & 0,7 & 0,49 & 0,26 & 0,39 \\
\hline $\begin{array}{l}\text { Efficiency of assets utilization } \\
\text { for production (revenue/assets) }\end{array}$ & 0,6 & 0,75 & 1,3 & 1,2 & 0,67 & 1,21 & 0,6 \\
\hline Place in the ranking & 1 & 2 & 3 & 4 & 5 & 6 & 7 \\
\hline
\end{tabular}

Calculated by the authors on the basis of financial statements of enterprises

utilization, which determine how quickly invested funds will return to investor and what income he will receive. Abovementioned calculations indicate that financial condition of the majority of agrarian enterprises is satisfactory, since the bigger part of business activities is financed by own working capital, and these enterprises have satisfactory profitability indicators.

\section{Findings}

In order to determine real investment attractiveness of agrarian enterprise, it is necessary to evaluate its complexity taking into account production and financial potential, as well as the potential of business activity and production efficiency. Such approach can be fully implemented in both inflationary and stable economy.
Investment attractiveness plays an important role in activation of investment processes. In the conditions of limited resources and intense competition between enterprises for obtaining financial resources, arises the issue regarding creation in investors of the idea of enterprise as attractive investment object - formation of investment attractiveness. The role of determining investment attractiveness of enterprises lies in the fact that potential investors need to convince expediency of investments with specific indicators.

\section{Conclusions}

Methodological approaches of different authors have some disadvantages, especially they do not take into account industry specifics of enterprise, are based 
on cumbersome multifactorial models, narrowing the range of analytical assessment. Hence, there is a need to develop rating generalization indicator that would enable to quickly and objectively evaluate investment attractiveness of enterprise and to select from its certain number of most reliable potential investment objects.
Proposed calculation methods cover all the major processes occurring in different functional sectors of the internal environment of agrarian enterprise, which ensures a systematic view of the enterprise, which enables to identify all the strengths and weaknesses, as well as to create a strategy for the prospective development on this basis.

\section{References:}

Order of the Agency for the Prevention of Bankruptcy of Enterprises and Organizations (1998). Metodika integralnoi ocinki investicijnoï privablivosti pidpryiemstv ta organizacij [Methodology of Integral Assessment of Investment Attractiveness of Enterprises and Organizations] (electronic source), Available at: http://zakon4.rada.gov.ua/laws/show/z0214-98 (accessed 21 December 2017).

Ponomarenko, V. S., Grynova, V. M., Lysytsa, N. M., Yastremska, O. M. (2003). Ekonomichni ta socialni aspekti upravlinnya investicijnoyu diyalnistyu [Economic and social aspects of investment activity management] Kharkiv: KhDEU. (in Ukrainian)

Yastremska, O. M. (2004). Investicijna diyalnist promislovih pidprijmstv: metodichni ta metodichni zasadi: naukove vidannya [Investment activity of industrial enterprises: methodological and methodical principles: Scientific publication] Kharkiv: KhDEU. (in Ukrainian)

Borshch, I. M., Gerasimova, S. V. (2007). Investicii: teoriya ta praktika: kerivnictvo - 2 vidannya [Investing: Theory and Practice: Manual - 2nd Edition]. Kiev: Znannya. (in Ukrainian)

Vakhovych, I. M., Oleksandrenko, I. V., Zabedyk, M. S. (2014). Metodika ocinyuvannya investicijnoi privablivosti pidpriemstva [The method of estimation of investment attractiveness of the enterprise]. Actual problems of the economy, no. 11 (161), pp. 154-160.

Pilipenko, O. I. (2010). Analiz investicijnoi privablivosti pidprijmstva: oglyad metodik [Analysis of investment attractiveness of enterprise: overview of techniques]. International collection of scientific works, vol. (13), pp. 324-330.

Blank, I. A. (2001). Investicionnyj menedzhment: ucheb. Kurs [Investment Management: Study Course]. Kiev: Elga-N, Nika-Center. (in Ukrainian)

Gaidutsky, A. P. (2004). Ocinka investicijnoi privablivosti ekonomiki [Estimation of the investment attractiveness of the economy]. Economy and Forecasting, no. 3, pp. 119-128.

Chernysh, S. S. (2013). Oglyad metodik analizu investicijnoi privablivosti pidprijmstva [An overview of analysis methods of investment attractiveness of enterprise]. Innovative economy, no. 5, pp. 87-92.

Gotra, I. V. (2017). Teoretichni osnovi upravlinnya innovacijnim rozvitkom agropromislovogo virobnictva Ukraini [Theoretical bases of management of innovative development of agro-industrial production of Ukraine]. Scientific Bulletin of Mukachevo State University, vol. 1 (7), pp. 16-21.

Skrypnyk, Y. V. (2016). Rejtingovo-analitichna ocinka investicijnoi privablivosti silskogospodarskogo pidpriymstva [Rating and analytical estimation of investment attractiveness of agricultural enterprise]. Economics and society, no. 3, pp. 477-448. 